The Canadian Mineralogist

Vol. 42, pp. 1667-1681 (2004)

\title{
CRYSTAL GROWTH OF SCHOEPITE ON THE (104) SURFACE OF CALCITE
}

\author{
Michael SCHINDLER ${ }^{\S}$ AND ANDREW PUTNIS \\ Institut für Mineralogie, Universität Münster, Corrensstr. 24, D-48149 Münster, Germany
}

\begin{abstract}
Schoepite, $\left[\left(\mathrm{UO}_{2}\right)_{8} \mathrm{O}_{2}(\mathrm{OH})_{12}\right]\left(\mathrm{H}_{2} \mathrm{O}\right)_{12}$, precipitates through interaction of acidic and basic uranyl solutions with calcite. The uranyl solutions have $\left(\mathrm{UO}_{2}\right)^{2+}$ concentrations between 1.5 and $50 \mathrm{mmol} \mathrm{L}^{-1}$, and initial $\mathrm{pH}$ values of $2.5,4.5$ and 10.0. Examinations with the atomic force microscope (AFM) reveal different morphologies of schoepite crystals grown on the (104) surface of calcite. Crystals grown during in situ experiments with uranyl nitrate solutions (initial $\mathrm{pH}=2.5$ ) have a platy morphology, and their prominent (001) faces are defined by [210] edges. Crystals grown during in situ experiments with uranyl acetate solution (initial $\mathrm{pH}=4.5$ ) seem more bulky, with poorly defined rectangular (001) faces. Examinations of calcite surfaces after interaction with a slightly acidic solution for three days (final $\mathrm{pH}$ between 5.5 and 6.5 ) show platy asymmetrical crystals with prominent (001) faces that are defined by [100], [010], [120], and [110] edges. Experiments with basic solutions after three weeks (final pH between 7.5 and 8.0) show bulky rectangular crystals of schoepite, in which the (001) face is mainly defined by [100] and [010] edges. The different thicknesses of schoepite crystals in the in situ experiments are explained by the different growth-rates of S and $\mathrm{F}$ faces in solutions with different saturation-indices with respect to schoepite. The occurrence of edges on the (001) face of schoepite crystals is explained by structural parameters of the chains of polyhedra parallel to the edges and the $\mathrm{pH}$ of the solution.
\end{abstract}

Keywords: schoepite, calcite, crystal growth, morphology, $\mathrm{pH}$ value, uranyl mineral.

\section{SOMMAIRE}

La schoepite, $\left[\left(\mathrm{UO}_{2}\right)_{8} \mathrm{O}_{2}(\mathrm{OH})_{12}\right]\left(\mathrm{H}_{2} \mathrm{O}\right)_{12}$, cristallise suite à une interaction de solutions uranylées acides ou basiques avec la calcite. Ces solutions uranylées possèdent une concentration de $\left(\mathrm{UO}_{2}\right)^{2+}$ entre 1.5 et $50 \mathrm{mmol} \mathrm{L}^{-1}$, et une valeur initiale de $\mathrm{pH}$ de 2.5, 4.5 ou 10.0. Un examen des cristaux avec le microscope à force atomique (AFM) révèle les morphologies distinctes des cristaux de schoepite formés sur la surface (104) de la calcite. Les cristaux formés au cours des expériences in situ avec une solution de nitrate uranylée ( $\mathrm{pH}$ initial $=2.5$ ) ont une morphologie en plaquettes, et leur face proéminente $(001)$ est définie par des arêtes [210]. Les cristaux formés au cours des expériences in situ avec une solution d'acétate uranylée $(\mathrm{pH}$ initial $=4.5)$ semblent plus trappus, avec des faces rectangulaires (001) de piètre qualité. Un examen des surfaces de calcite suite à une interaction avec une solution légèrement acide pour trois jours ( $\mathrm{pH}$ final entre 5.5 et 6.5) montre des cristaux en plaquettes assymétriques avec des faces (001) proéminentes définies par les arêtes [100], [010], [120], et [110]. Des expériences avec des solutions basiques après trois semaines ( $\mathrm{pH}$ final entre 7.5 et 8.0) révèlent de gros cristaux rectangulaires de schoepite, dans lesquels la face (001) est surtout définie par les arêtes [100] et [010]. Les épaisseurs différentes des cristaux de schoepite dans les expériences in situ seraient dues aux taux de croissance différents des faces $\mathrm{S}$ et $\mathrm{F}$ des solutions ayant des indices de saturation différents par rapport à la schoepite. La présence d'arêtes sur la face (001) des cristaux de schoepite dépendrait des paramètres structuraux des chaînes de polyèdres parallèles aux arêtes et au pH de la solution.

Mots-clés: schoepite, calcite, croissance cristalline, morphologie, valeur du pH, minéral uranylé.

$\S \quad$ Present address: Department of Geological Sciences, University of Manitoba, Winnipeg, Manitoba, R3T 2N2, Canada. E-mail address: mschindl@lakeheadu.ca 


\section{INTRODUCTION}

Schoepite, $\left[\left(\mathrm{UO}_{2}\right)_{8} \mathrm{O}_{2}(\mathrm{OH})_{12}\right]\left(\mathrm{H}_{2} \mathrm{O}\right)_{12}$, occurs in many oxidized uranium deposits in a complex assemblage of uranyl minerals that form where uraninite has been exposed to oxidizing meteoric water (Frondel 1958, Deliens 1977, Finch et al. 1992, Finch \& Ewing 1992). Schoepite and other uranyl minerals have also been identified as products of corrosion of $\mathrm{UO}_{2}$ and spent nuclear fuel (Wadsen 1977, Wang \& Katayama 1982, Forsyth \& Werme 1992, Sunder et al. 1992, Wronkiewicz et al. 1992, 1996, Buck et al. 1997, 1998). Recently, the formation of schoepite was also observed on used depleted uranium ammunition in Kosovo (United Nations Environmental Program 2001).

In nature, acidic and basic uranyl-bearing solutions can come in contact with rock-forming minerals such as calcite. In order to understand the corresponding processes of growth of uranyl minerals on a nanoscale, we examined the interaction of highly concentrated uranyl solutions with the (104) surface of calcite using atomic force microscopy (AFM). In this paper, we aim to show that 1) solutions with different values of $\mathrm{pH}$ and uranyl concentrations result in different mechanisms of crystal growth of schoepite on the (104) surface of calcite, and 2 ) the bond-valence approach to the crystal morphology of uranyl minerals developed by Schindler et al. (2004a, b) can be used to explain variations in morphology with the conditions of the solution.

\section{The Calcite Substrate: Previous Examinations of InTERACTION WITH $\mathrm{U}^{6+}$-Bearing Solutions}

There are several experimental studies concerning the uptake of $\mathrm{U}^{6+}$ by calcite through adsorption and coprecipitation (Caroll et al. 1992, Meece \& Benninger 1993, Geipel et al. 1997, Mason et al. 1997, Reeder et al. 2000, 2001, Morse et al. 1984). Kitano \& Oomori (1971) and Meece \& Benninger (1993) showed that hexavalent uranium is preferentially incorporated into aragonite relative to calcite, and Reeder et al. (2000) reported that aragonite and calcite can coprecipitate from aqueous solution with up to 10000 and $1900 \mathrm{ppm}$ $\mathrm{U}^{6+}$, respectively. Reeder et al. (2001) examined in detail the incorporation of uranyl carbonate species into the calcite structure at $\mathrm{pH} 7.6$ and 8.2.

The interaction of uranyl-bearing solutions with calcite was also examined with extended X-ray absorption fine structure spectroscopy (EXAFS), X-ray photoelectron spectroscopy (XPS), and time-resolved laser-induced fluorescence spectroscopy (TXRLFS) (Geipel $e t$ al. 1997, Yu et al. 1998). These investigators mainly showed that uranyl hydroxide and uranyl carbonate coatings form on the corresponding surfaces of the carbonate minerals. Caroll et al. (1992) examined uranylsolution interactions at the calcite-solution interface. They observed precipitation of an unidentified Ca-uranyl compound on calcite, and noted differences in the corresponding crystal-morphologies at $\mathrm{pH}=4.3$ and $\mathrm{pH}$ $=8$. The corresponding back-scattered electron images revealed that the uranyl phase precipitated penetrates into calcite, and is not merely at the surface.

\section{Morphology of Natural CRystals of Schoepite}

Figure 1a shows the typical morphology of natural crystals of schoepite from the Shinkolobwe mine, Tantara, Shaba, Democratic Republic of Congo. The crystals have a prominent (001) face, which is slightly elongate along [010]. The edges defining the (001) face have the indices [120], [110], [100], and [010] (http:// trinityminerals.com/sm/uranium/shtml). Figure $1 \mathrm{~b}$ shows prismatic crystals of schoepite from the Shinkolobwe mine, where [100], [010] and [110] edges define the (001) face, whereas the [120] edges occur between (210) and (211) faces (Walker 1923). Figure 1c shows typical rectangular crystals of schoepite from Kasolo, Democratic Republic of Congo (Perloff 1998). The morphology of their (001) face is mainly characterized by [100] and [010] edges and, to a lesser extent, by the [110] edge (Palache et al. 1944, Fig. 1d).

\section{Structure and Stability of Schoepite}

Schoepite belongs to the group of uranyl-hydroxyhydrate minerals. The structure of these minerals is characterized by a prominent uranyl-sheet structural unit, which is either neutral or negatively charged; e.g. $\left[\left(\mathrm{UO}_{2}\right)_{8} \mathrm{O}_{2}(\mathrm{OH})_{12}\right]^{0}$ in schoepite (Finch et al. 1996) and $\left[\left(\mathrm{UO}_{2}\right)_{3} \mathrm{O}_{2}(\mathrm{OH})_{3}\right]^{-}$in becquerelite, $\mathrm{Ca}\left[\left(\mathrm{UO}_{2}\right)_{3} \mathrm{O}_{2}\right.$ $\left.(\mathrm{OH})_{3}\right]_{2}\left(\mathrm{H}_{2} \mathrm{O}\right)_{8}$ (Burns \& $\mathrm{Li}$ 2002). These sheets form through polymerization of aqueous uranyl-hydroxy-hydrate species such as $\left[\left(\mathrm{UO}_{2}\right)_{3}(\mathrm{OH})_{5}\left(\mathrm{H}_{2} \mathrm{O}\right)_{5}\right]^{+}$in weakly acidic to weakly basic uranyl-bearing solutions. Between the mainly anionic sheets, there are cationic interstitial complexes with alkaline and alkaline-earth cations, and $\left(\mathrm{H}_{2} \mathrm{O}\right)$ and $(\mathrm{OH})^{-}$groups.

In schoepite, $\mathrm{U}^{6+}$ is [7]-coordinated by two apical uranyl O-atoms and five $(\mathrm{OH})$ groups or four $(\mathrm{OH})$ groups and one $\mathrm{O}$ atom equatorially (Finch et al. 1996). Its crystal structure shows space-group symmetry $P 2{ }_{1} \mathrm{ca}$ (orthorhombic) with $a 14.337, b 16.813$ and $c 14.731 \AA$.

Figure 2a shows parts of a (001) layer in schoepite, in which the pentagonal bipyramidal uranyl polyhedra share common edges via equatorial $\mathrm{O}^{2-}$ and $(\mathrm{OH})^{-}$ ligands. The apical $\mathrm{U}=\mathrm{O}$ bonds are not involved in the linkage between uranyl polyhedra, and point up and down into the interstices. The additional $\left(\mathrm{H}_{2} \mathrm{O}\right)$ groups are located between the layers and link them via weak hydrogen bonds.

Schoepite alters to metaschoepite, $\left[\left(\mathrm{UO}_{2}\right)_{8} \mathrm{O}(\mathrm{OH})_{12}\right]$ $\left(\mathrm{H}_{2} \mathrm{O}\right)_{10}$ and "dehydrated schoepite", $\mathrm{UO}_{3} \bullet\left(\mathrm{H}_{2} \mathrm{O}\right)_{0.75}$. Natural schoepite spontaneously dehydrates to metaschoepite, and natural crystals consist of intergrown schoepite, metaschoepite and "dehydrated schoepite" (Christ \& Clark 1960, Finch et al. 1998). 


\section{Prediction of Crystal Morphologies of URANYL-SheEt Minerals}

Schindler et al. (2004a) developed a new approach to calculate the stability of edges on basal faces of uranyl-sheet minerals. They showed that the occurrence of edges on basal faces of uranyl-sheet minerals depends on the interaction of the corresponding anion-terminations with the aqueous solution at different $\mathrm{pH}$ and degrees of supersaturation. The structural parameter and chemical composition of the chains of polyhedra parallel to the edge, the arrangement of the interstitial complexes, and the shift between the layers control the degree of interaction between the anion terminations on an edge with complexes in aqueous solution. On the basis of these structural parameters, Schindler et al. (2004b) predicted the occurrence of edges on the basal face of uranyl-sheet minerals and compared those with observations on minerals and synthetic compounds. The occurrence of faces and edges on the final morphology of a crystal does, however, also depend on the conditions during crystal growth, e.g., supersaturation and $\mathrm{pH}$.

Supersaturation, $p H$ of the solution

and the point of zero charge of a surface

The effects of $\mathrm{pH}$ and supersaturation on surfacecontrolled dissolution or crystal growth are well known. Surface-controlled dissolution occurs through interaction of anion or cation terminations on the surface with the aqueous species in the solution. This interaction may involve protonation, deprotonation, attachment of cationic aqueous-species and the acceptance of hydrogen bonds. All these factors mainly depend on the individual pKa values (equilibrium constants of the corresponding acid-base reactions) of the anion terminations, the point of zero charge of the specific surface (see below) and on the $\mathrm{pH}$ of the solution. The degree of interaction between any surface feature, e.g., face, edge, step or kink, and the aqueous species correlates with the rate of dissolution and crystal growth, i.e., the higher the interaction between a surface and the aqueous solution, the higher the rate of dissolution or crystal growth (Stumm 1992).

Surfaces can have a positive, negative or neutral netproton charge. A surface has a zero net-proton charge if its number of positively or negatively charged terminations is identical. The $\mathrm{pH}$ value of a solution at which a surface has a zero net-proton charge is called the point of zero net-proton charge, which we will designate as PZC (Schindler et al. 2004a). At the PZC, there is a low interaction between the surface and the aqueous solution. Hence, the rate of dissolution and growth of a mineral is at a minimum at the PZC. Because different faces, edges or kinks have different types of terminations, every one of those surface features has its specific PZC.
Schindler et al. (2004b) calculated a PZC of 7.0 for the (001) face of schoepite (the dominant one) and the range in PZC for all edges in the range 6.5-7.1 on the basis of intrinsic acidity constants of acid-base reactions on the equatorial anion-terminations. If the $\mathrm{pH}$ of the solution is within the PZC range of the edges for a given saturation-index, there is the lowest degree of interaction between edge and aqueous solution.

Similar considerations can be applied to the saturation index $\beta$. At equilibrium, the saturation index $\beta$ of a solution is 1 , and there is minimum interaction between a surface and aqueous solution. If the supersaturation increases or decreases by $\Delta \beta$, the interaction between aqueous solution and edges increases. These considerations do not take into account the occurrence of possible inner-sphere and outer-sphere complexes, which also contribute to the overall charge of a surface and to the overall interaction between surface and aqueous solution.

Chains of polyhedra in schoepite and the degrees of interaction between the corresponding edges and the aqueous solution

Figure 2a shows the uranyl sheet of schoepite with different chains of polyhedra parallel to the [010], [100], [110], [120], and [210] edges. Schindler et al. (2004b) showed that the structural parameters of these chains indicate that the interaction between the edges and the solution increases in the following sequence: [010] $<<$ $[100]<<[120]=[110]<<[210]$. Hence, they predicted that the edges [010] and [100] should always occur independently of $\mathrm{pH}$ or supersaturation, whereas the occurrence of [120] and [110] edges depends on the differences between $\mathrm{pH}$ and the PZC and on the saturation index of the solution. The [210] edge has the highest interaction of all edges and may not be observed, even for crystal growth in a saturated solution, with a $\mathrm{pH}$ equal to the PZC. In this way, the edges [100], [120], [010] and [110] may define the (001) face of a crystal growing in a slightly supersaturated solution, with a $\mathrm{pH}$ close to the PZC (Fig. 2b), whereas at high supersaturation and large differences between $\mathrm{pH}$ and $\mathrm{PZC}$, only the [100] and [010] edges may define the (001) face of the corresponding crystals (Fig. 2c).

\section{EXPERIMENTAL}

Crystal growth of schoepite on the (104) surface of calcite was observed after batch or in situ experiments using atomic force microscopy (AFM; Digital Instruments Nanoscope III Multimode and Dimensional 3000). The in situ experiments were carried out with a fluid cell from Digital Instruments. The calcite samples were freshly cleaved from a block of optically clear Iceland spar. The in situ experiments were free-drift ex- 
(a)
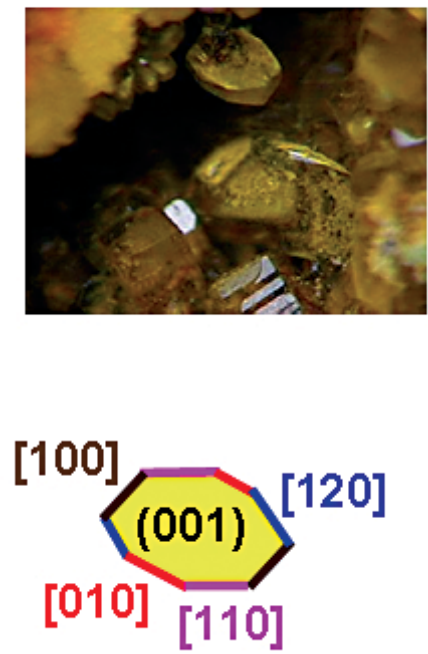

(b)

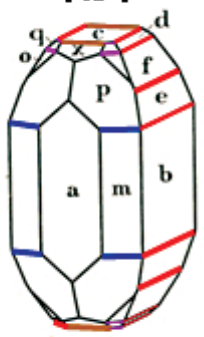

(c)

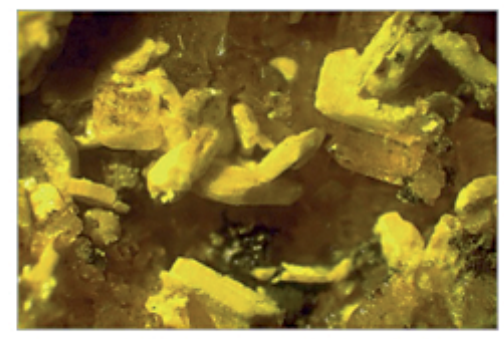

FIG. 1. (a) Natural crystals of schoepite with a prominent (001) face, which is defined by [120], [110], [100] and, [010] edges (Perloff 1998). (b) Prismatic schoepite crystal with a (001) face defined by [100], [010] and [110] edges; [120] edges occur between the (210) and (211) faces (indicated as (m and P) (Walker 1923). (c) Schoepite crystals from Kasolo, Democratic Republic of Congo (Perloff 1998). (d) A crystal showing a dominant (001) face with [100], [010] and minor [110] edges (Palache et al. 1944).

periments: after injection of the solution into the fluid cell, the fluid flow was stopped while the images of the growth or dissolution experiments were recorded. The surface of calcite was scanned in contact and tapping mode.

Contact AFM potentially affects dissolution and crystal-growth processes, because the AFM tip exerts a local pressure on the sample surface, with a loading force in the nanonewton range. In order to verify that contact mode and scanning direction did not affect the shape and orientation of the crystals, we always scanned an area in orthogonal directions.

\section{Crystal-growth experiments \\ of schoepite in acidic solutions}

The experiments were carried out with different molar ratios of uranyl nitrate and uranyl acetate. The concentrations of the uranyl salts varied between 1.5 and $10 \mathrm{mmol} \mathrm{L}^{-1}$. Depending on the concentration, the starting $\mathrm{pH}$ value of the uranyl nitrate solutions was invariably close to 2.5 , and that of the uranyl acetate solutions, close to 4.5 . In the batch experiments, $30 \mathrm{mg}$ of calcite was washed in distilled water and brought in contact with $5 \mathrm{~mL}$ of the corresponding solution. The size of the calcite crystals was on average $3 \times 3$ [(104 surface] $\times 2 \mathrm{~mm}$. All batch experiments were performed at $25^{\circ} \mathrm{C}$, with contact times between 2 and 7 days. At the end of each experiment, the $\mathrm{pH}$ value was $5.5-6.0$ for uranyl nitrate solutions and 6.0-6.5 for uranyl acetate solutions.

\section{Crystal-growth experiments}

of schoepite in basic solutions

The experiments under strongly basic conditions were performed with different molar ratios of uranyl nitrate, $\mathrm{Na}_{2} \mathrm{CO}_{3}$ and $\mathrm{CaCl}_{2}$. The concentrations of uranyl nitrate were $0.5,1,5,10$ and $50 \mathrm{mmol} \mathrm{L}^{-1}$. The molar ratios of uranyl nitrate $+\mathrm{Na}_{2} \mathrm{CO}_{3}$ and uranyl nitrate + $\mathrm{CaCl}_{2}+\mathrm{Na}_{2} \mathrm{CO}_{3}$ were $1: 4$ and $1: 2: 3$, with maximum concentrations of $50 \mathrm{mmol} \mathrm{L}^{-1}\left(\mathrm{UO}_{2}\right)\left(\mathrm{NO}_{3}\right)_{2}, 100 \mathrm{mmol}$ $\mathrm{L}^{-1} \mathrm{CaCl}_{2}$ and $150 \mathrm{mmol} \mathrm{L}^{-1} \mathrm{Na}_{2} \mathrm{CO}_{3}$. At the beginning of each experiment, $30 \mathrm{mg}$ of freshly washed crystals of calcite were brought in contact with $5 \mathrm{~mL}$ of the corresponding solution. The starting value of $\mathrm{pH}$ was invariably between 9.5 and 10.5 , and the final value of $\mathrm{pH}$, between 7.5 and 8.0. All batch experiments were carried out at $25^{\circ} \mathrm{C}$, with contact times between 2 days and 3 months.

\section{Identification of minerals on the surface of calcite}

After all experiments, the overgrown solid phases were scraped from the calcite surface, and subsequently analyzed by X-ray powder diffraction with a Philips 
PW3040 diffractometer. In the case of the in situ experiments, the overgrown phases were allowed to develop on the calcite surface for 24 hours.

Less soluble overgrown phases were washed with distilled water and further examined by scanning electron microscopy (SEM). Semiquantitative chemical analyses were performed using the JEOL microscope JSM-6300F and the EDAX system from Oxford Instruments. The surface of each calcite crystal was also examined by optical reflection microscopy.

All uranyl oxide salts that have been identified on the calcite surface can be clearly distinguished by their colors and fluorescence, i.e., crystals of schoepite and dehydrated schoepite, $\left[\left(\mathrm{UO}_{2}\right)_{8} \mathrm{O}_{2}(\mathrm{OH})_{12}\right]\left(\mathrm{H}_{2} \mathrm{O}\right)_{12}$, are usually yellow, becquerelite, $\mathrm{Ca}\left[\left(\mathrm{UO}_{2}\right)_{3} \mathrm{O}_{2}(\mathrm{OH})_{3}\right]_{2}$ $\left(\mathrm{H}_{2} \mathrm{O}\right)_{8}$, appears reddish brown or orange on the calcite surface, wyartite, $\mathrm{Ca}\left[\mathrm{U}^{5+}\left(\mathrm{UO}_{2}\right)_{2}\left(\mathrm{CO}_{3}\right) \mathrm{O}_{4}(\mathrm{OH})\right]\left(\mathrm{H}_{2} \mathrm{O}\right)_{7}$, is pink, and liebigite, $\mathrm{Ca}_{2}\left[\left(\mathrm{UO}_{2}\right)\left(\mathrm{CO}_{3}\right)_{3}\right]\left(\mathrm{H}_{2} \mathrm{O}\right)_{11}$, is green and fluoresces (Schindler et al. 2004c). Moreover, we could select specific areas on the (104) surface of calcite with more or less one particular phase. We scanned these areas with the atomic force microscope and obtained three-dimensional images of the corresponding overgrown crystals. The crystal habits and forms of crystal faces were then compared with the morphology of crystals from mineral samples or with drawings of crystal morphologies in the literature (e.g., Fig. 1).

Calculations of Saturation Index and Speciation of the Uranyl Ion During THE IN SITU EXPERIMENTS

The saturation index with respect to schoepite, $\beta_{\text {schoepite, }}$ can be calculated using the following expression:

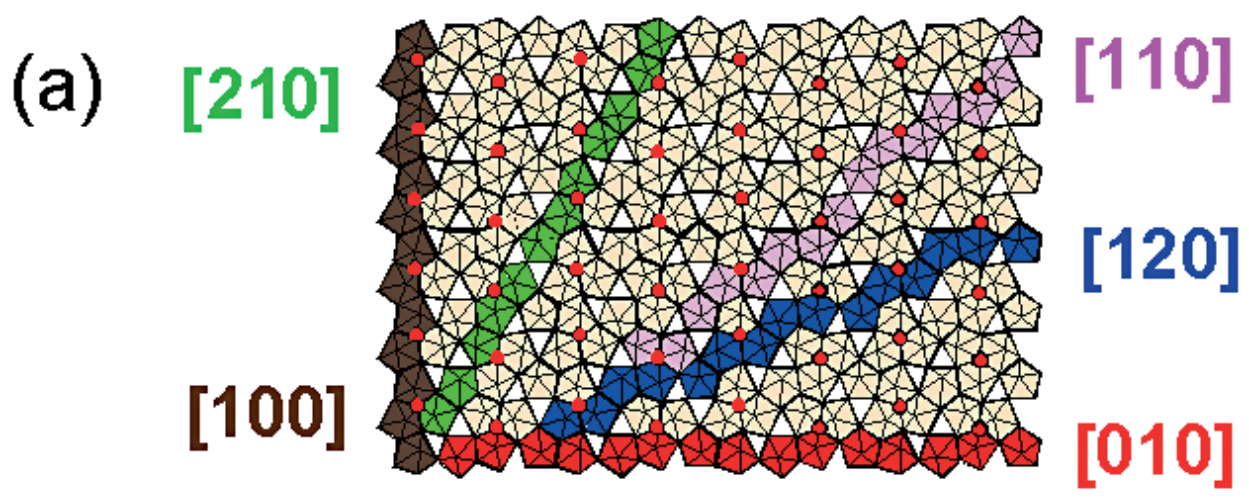

(b)

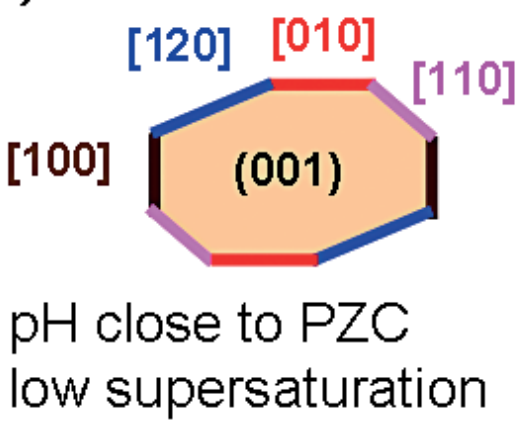

[100]

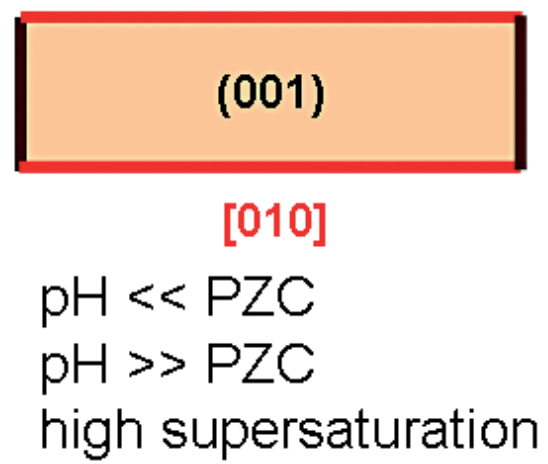

FIG. 2. (a) Polyhedral representation of the uranyl-hydroxy-hydrate sheet in schoepite, $\left[\left(\mathrm{UO}_{2}\right)_{8} \mathrm{O}_{2}(\mathrm{OH})_{12}\right]\left(\mathrm{H}_{2} \mathrm{O}\right)_{12}$; chains of polyhedra parallel [100], [010], [120], [110] and [210] are highlighted in brown, red, blue, pink, and green, respectively; equatorial $\mathrm{O}^{2-}$ ligands in the uranyl polyhedra are indicated as red circles. (b), (c) Predicted occurrence of edges on schoepite crystals grown in a solution with (b) a pH close to PZC and with a low supersaturation with respect to schoepite, or (c) a pH with large differences to PZC or with a high supersaturation with respect to schoepite. 


$$
\beta_{\text {schoopite }}=\frac{\frac{a\left(\mathrm{UO}_{2}^{2+}\right) a\left(\mathrm{H}_{2} \mathrm{O}\right)^{3}}{a_{\text {schoepite }} a\left(\mathrm{H}^{+}\right)^{2}}}{K_{\text {schoepite }}}
$$

where $a\left(\mathrm{UO}_{2}\right)^{2+}, a\left(\mathrm{H}_{2} \mathrm{O}\right)$, and $a\left(\mathrm{H}^{+}\right)$are the activities in the aqueous solution of the uranyl cation, $\mathrm{H}_{2} \mathrm{O}$ and the protons, respectively, and $K_{\text {schoepite }}$ is the solubility product of schoepite. The activity of schoepite is one, and, for low concentrations in solution, the activity of water can be also considered equal to one. Therefore, equation (1) is simplified as:

$$
\beta_{\text {schoepite }}=\frac{a\left(\mathrm{UO}_{2}^{2+}\right)}{a\left(\mathrm{H}^{+}\right)^{2} K_{\text {schoepite }}}
$$

The value of the solubility product of schoepite at $25^{\circ} \mathrm{C}$ was experimentally determined by Torrero et al. (1994): $K_{\text {schoepite }}=10^{5.38}$. In order to calculate saturation indices with respect to schoepite using equation (2), it is necessary to know the activity of the uranyl cation, $a\left(\mathrm{UO}^{2+}{ }_{2}\right)$, and the $\mathrm{pH}$ of the solutions. In the case of the solution used in our experiments, the $\mathrm{pH}$ was directly measured, and $a\left(\mathrm{UO}^{2+}{ }_{2}\right)$ was calculated using the freely available computer code for chemical speciation Visual MINTEQ 2.22 (Gustafsson 2003).

The critical issue in the calculation of saturation indices with respect to schoepite is the change in speciation of the uranyl ion during the interaction of an acidic solution with calcite. For example, the most common uranyl aqueous species in acidic uranyl nitrate and uranyl acetate solutions are $\mathrm{UO}_{2}{ }^{2+}, \mathrm{UO}_{2} \mathrm{OH}^{+},\left(\mathrm{UO}_{2}\right)_{2}$ $(\mathrm{OH})_{2}{ }^{2+},\left(\mathrm{UO}_{2}\right)_{3}(\mathrm{OH})_{5}{ }^{+}, \mathrm{UO}_{2} \mathrm{NO}_{3}{ }^{+}, \mathrm{UO}_{2}-(\text { Acetate })_{2}$ (aq) and $\mathrm{UO}_{2}-$ Acetate $^{+}$(Grenthe et al. 1992, Gustafsson 2003). Increasing dissolution of $\mathrm{CaCO}_{3}$ and increasing $\mathrm{pH}$ result in an increase in the activity of uranyl carbonate species such as $\mathrm{UO}_{2} \mathrm{CO}_{3}(\mathrm{aq}), \mathrm{UO}_{2}\left(\mathrm{CO}_{3}\right)_{2}{ }^{2-}$, and $\mathrm{UO}_{2}\left(\mathrm{CO}_{3}\right)_{3}{ }^{4-}$. The amount of dissolved $\mathrm{CaCO}_{3}$ during in situ experiments can be extrapolated via the measured change in $\mathrm{pH}$. On the basis of the chemical reaction

$$
\mathrm{CaCO}_{3}+2 \mathrm{H}^{+} \leftrightarrow \mathrm{H}_{2} \mathrm{CO}_{3} *+\mathrm{Ca}^{2+}
$$

an increase in $\mathrm{pH}$ from 2.5 to 5.5 in the uranyl nitrate solution yields approximate $\mathrm{H}_{2} \mathrm{CO}_{3} *$ and $\mathrm{Ca}^{2+}$ concentrations of $\sim\left(10^{-2.5} / 2\right) \mathrm{mol} \mathrm{L}^{-1}\left[\mathrm{H}_{2} \mathrm{CO}_{3} *=\mathrm{H}_{2} \mathrm{CO}_{3}(\mathrm{aq})\right.$ and $\left.\mathrm{CO}_{2}(\mathrm{aq})\right]$. In the same way, an increase in $\mathrm{pH}$ from 4.5 to 6.5 in the uranyl acetate solution results in approximate $\mathrm{H}_{2} \mathrm{CO}_{3} *$ and $\mathrm{Ca}^{2+}$ concentrations of $\sim\left(10^{-4.5} / 2\right) \mathrm{mol} \mathrm{L}^{-1}$. We used these concentrations to calculate saturation indices with respect to schoepite for different values of $\mathrm{pH}$ in a $10 \mathrm{mmol} \mathrm{L}^{-1}$ uranyl nitrate and in 5 and $10 \mathrm{mmol} \mathrm{L}^{-1}$ uranyl actetate solutions
(Tables 1,2). These calculations indicate that $\left(\mathrm{UO}_{2}\right)_{3}(\mathrm{OH})_{5}{ }^{+}$is the dominant uranyl-bearing aqueous species in all solutions at $\mathrm{pH}$ values above 4.5. Tables 1 and 2 also list the distribution of uranyl aqueous species at the final $\mathrm{pH}$ value of each in situ experiment.

\section{RESULTS}

In the in situ experiments with uranyl acetate and uranyl nitrate solution, a yellow precipitate occurs on the calcite surface after a few minutes. The X-ray-diffraction pattern of the product of the uranyl nitrate experiment shows a very low peak:background ratio, which indicates a high ratio of X-ray-amorphous to crystalline material. The three strongest peaks correspond to the strongest peaks of schoepite at $d_{002}=7.366 \AA$, $d_{242}=3.253 \AA$ and $d_{240}=3.626 \AA$ (Hill 1999). This is in agreement with the results of a semiquantitative chemical analysis (SEM), which shows that particles of the precipitate contain only minor amounts of $\mathrm{Ca}^{2+}$. On the

\begin{tabular}{|c|c|c|}
\hline $\mathrm{pH}$ & $\begin{array}{l}\text { Saturation } \\
\text { index }\end{array}$ & $\begin{array}{c}\text { Distribution of } \\
\text { uranyl-aqueous species } \\
\text { at } \mathrm{pH} 6.5\end{array}$ \\
\hline \multicolumn{3}{|c|}{$5 \mathrm{mmol} \mathrm{L}^{-1}$} \\
\hline $\begin{array}{l}4.5 \\
5.5 \\
6.0 \\
6.5 \\
7.0\end{array}$ & $\begin{array}{c}1.62 \\
5.0 \\
7.50 \\
11.04 \\
16.21\end{array}$ & $\begin{array}{c}0.048 \% \mathrm{UO}_{2}-(\text { Acetate })_{2}(\mathrm{aq}) \\
0.067 \% \mathrm{UO}_{2}-\mathrm{Acetate}^{+} \\
0.023 \% \mathrm{UO}_{2} \mathrm{OH}^{+} \\
0.104 \%\left(\mathrm{UO}_{2}\right)_{2}(\mathrm{OH})_{2}{ }_{2}{ }^{2+} \\
99.676 \%\left(\mathrm{UO}_{2}\right)_{3}(\mathrm{OH})_{5}{ }^{+} \\
\left.0.025 \% \mathrm{UO}_{2} \mathrm{CO}_{3} \text { (aq) }\right) \\
0.049 \% \mathrm{UO}_{2}-(\text { Acetate })_{3}{ }^{-}\end{array}$ \\
\hline \multicolumn{3}{|c|}{$10 \mathrm{mmol} \mathrm{L}{ }^{-1}$} \\
\hline $\begin{array}{l}4.5 \\
5.5 \\
6.0 \\
6.5 \\
7.0\end{array}$ & $\begin{array}{r}1.97 \\
6.14 \\
9.31 \\
13.77 \\
20.41\end{array}$ & $\begin{array}{c}0.11 \% \mathrm{UO}_{2}-(\text { Acetate })_{2}(\mathrm{aq}) \\
0.08 \% \mathrm{UO}_{2}-\mathrm{Acetate}^{+} \\
0.02 \% \mathrm{UO}_{2} \mathrm{OH}^{+} \\
0.09 \%\left(\mathrm{UO}_{2}\right)_{2}(\mathrm{OH})_{2}{ }_{2+}{ }^{2+} \\
99.45 \%\left(\mathrm{UO}_{2}\right)_{3}(\mathrm{OH})_{5}{ }^{+} \\
0.02 \% \mathrm{UO}_{2} \mathrm{CO}_{3}(\mathrm{aq}) \\
0.23 \% \mathrm{UO}_{2}-(\text { Acetate })_{3}{ }^{-}\end{array}$ \\
\hline
\end{tabular}
basis of these results, we conclude that the crystalline

TABLE 1. SATURATION INDICES WITH RESPECT TO SCHOEPITE FOR
VALUES OF PH BETWEEN 2.5 AND 6.0, AND THE DISTRIBUTION OF
URANYL AQUEOUS SPECIES AT pH = 5.5 IN A $10 \mathrm{mmol} \mathrm{L-1}$
URANYL NITRATE SOLUTION


part of the precipitate has a chemical composition and structure similar to those of natural schoepite.

The X-ray powder-diffraction patterns of the yellow precipitate from uranyl acetate experiments indicate a much lower ratio of X-ray-amorphous to crystalline material and include up to six characteristic peaks of schoepite. Other yellow phases with the general chemical composition $\mathrm{UO}_{3} \bullet n \mathrm{H}_{2} \mathrm{O}(0.75<n<2)$ are for example $\alpha$ - and $\beta$ - $\left[\mathrm{UO}_{2}(\mathrm{OH})_{2}\right]$ (Taylor \& Hurst 1971) and dehydrated schoepite (Finch et al. 1998). Those compounds can be synthesized in acidic solution at temperatures above $80^{\circ} \mathrm{C}$ (Finch et al. 1998). There is no report that these phases precipitate from solutions at room temperature.

After the batch experiments in weakly acidic solution, we identified the uranyl-bearing phases schoepite, becquerelite and wyartite II on the calcite surface, whereas phases such as U-bearing calcite, liebigite, wyartite II, becquerelite and schoepite have been observed after the batch experiments in basic solution. In the latter experiment, the uranyl minerals wyartite II, becquerelite and schoepite started to precipitate when the $\mathrm{pH}$ value of the solution dropped below 8.5 (for more detail, see Schindler et al. 2004c).

\section{AFM OBSERVATIONS AT tHe IN SITU EXPERIMENTS AT $25^{\circ} \mathrm{C}$}

Calcite starts to dissolve in contact with acidic uranyl solutions. Through dissolution of calcite, the $\mathrm{pH}$ value of the solution rapidly increases and stabilizes after several days. Whereas $10 \mathrm{mmol} \mathrm{L}^{-1}$ uranyl nitrate and uranyl acetate solutions are undersaturated or slightly supersaturated with respect to schoepite, they become strongly supersaturated with respect to this phase once the $\mathrm{pH}$ increases to higher values (Tables 1 , 2). Such an increase in $\mathrm{pH}$ is related to the dissolution of calcite. Therefore, the resulting increase in supersaturation for schoepite essentially occurs at the calcite surface - solution interface. During the experiments, the quality of the AFM images decreases with enhanced precipitation of schoepite. In the case of $10 \mathrm{mmol} \mathrm{L}^{-1}$ uranyl nitrate and uranyl acetate solutions, well-resolved AFM images of the (001) faces of the schoepite crystals could be only recorded for the first 10 minutes of each in situ experiment. Reasons could be (a) the general low degree of crystallinity of the schoepite precipitate, (b) the large saturation-indices with respect to schoepite at this stage of the experiment, (c) strong interactions between the tip and the weakly attached crystals of schoepite on the calcite surface, and (d) precipitation of schoepite on the top of the cantilever.

\section{AFM observations of the in situ experiments} with a $10 \mathrm{mmol} \mathrm{L}^{-1}$ uranyl nitrate solutions

At the start of each growth experiment, deionized water was passed over the crystal to clean the cleaved
(104) calcite surface and to adjust the AFM parameters. This led to a slight dissolution of cleavage edges and to the formation of etch pits. The etch pits on calcite typically show a rhombohedral shape defined by [ $\overline{4} 41]$ and [481] edges.

Figure 3a shows an AFM image of a typical rhombohedral etch-pit before injection of a $10 \mathrm{mmol} \mathrm{L}^{-1}$ uranyl nitrate solution with $\mathrm{pH}=2.5$. Figures $3 \mathrm{~b}$ and $3 \mathrm{c}$ show the formation of a layer of fine-grained precipitate in the first four minutes after injection. Five minutes after injection, small elongate crystals of schoepite occur on top of the fine-grained precipitate (Figs. 3d-f). Edges on the overgrown layer of schoepite (after $c a$. 10 minutes), which are parallel to the longer and shorter axis of the schoepite crystals, also are formed (Fig. 3f).

\section{Morphology of the schoepite crystals}

As described above, the (001) face of schoepite is usually defined by [100], [010], [120] and [110] edges. The common [120] edge in natural schoepite encloses an acute angle of $46.3^{\circ}$ and an obtuse angle of $133.7^{\circ}$, the [110] edge, $80.9^{\circ}$ and $99.1^{\circ}$, and the [120] and [110] edge, $72.7^{\circ}$ and $107.3^{\circ}$. In contrast, the schoepite crystals formed on the calcite surface have corresponding angles of $c a .60^{\circ}$ and $120^{\circ}$, respectively (Fig. 4a). These angles occur between two chains of polyhedra parallel to [210] (more exactly, $59.7^{\circ}$ and $120.3^{\circ}$ ) in the schoepite layer (Fig. 4b). This finding clearly indicates that the (001) face of these schoepite crystals is defined by [210] edges rather than by [110] and [120] edges.

Figure $4 \mathrm{a}$ shows a cross section of a height image from one of the schoepite crystals formed five minutes after injection (Fig. 3d). It indicates that the average vertical distance between the arrows along the cross section is $4.293 \mathrm{~nm}$, which is approximately three unit cells in [001] $(3 \times 14.731 \AA \approx 4.3 \mathrm{~nm})$. The average lateral dimension of these first crystals of schoepite is ca. $750 \times 450 \mathrm{~nm}$ (Fig. 3d).

The schoepite crystals that formed after 10 minutes have similar lateral dimensions $(800 \times 500 \mathrm{~nm})$, but their average height increased to five unit cells $(\sim 7.5$ $\mathrm{nm}$ ) (Figs. 3e-f). The maximum size of the schoepite crystals, observed after 15 minutes, on average, is 1200 $\times 750 \times 92 \mathrm{~nm}$ (not shown).

\section{AFM observations of the in situ experiments

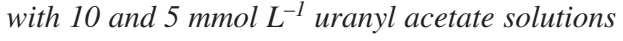

A $10 \mathrm{mmol} \mathrm{L}^{-1}$ uranyl acetate solution has an initial $\mathrm{pH}$ value around 4.5 and a final value around 6.5. It has, therefore, higher initial and final saturation-indices with respect to schoepite than a $10 \mathrm{mmol} \mathrm{L}^{-1}$ uranyl nitrate solution (Tables 1, 2). On the basis of these data, one would expect that precipitation of schoepite should occur shortly after injection of the uranyl acetate solution. This is indeed the case: a small growth-induced island is observed on the calcite surface in the first two min- 


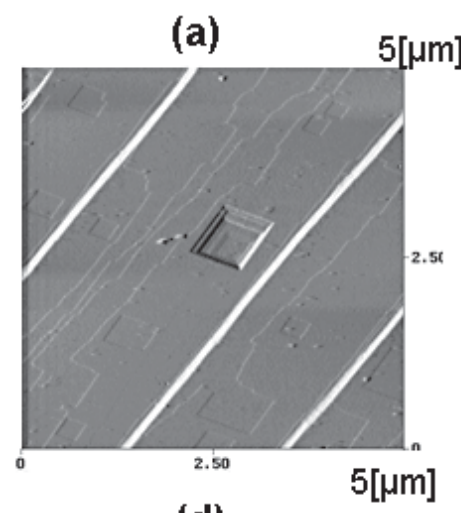

(d)

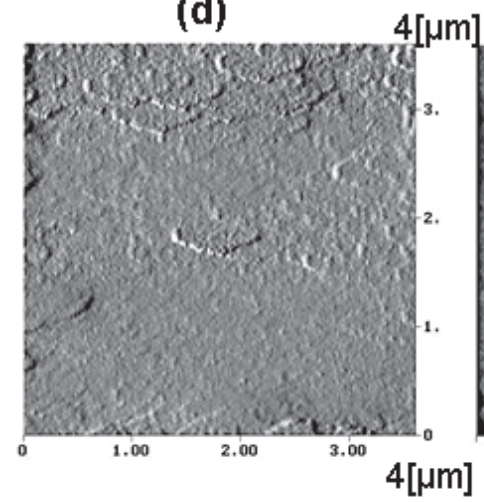

(b)

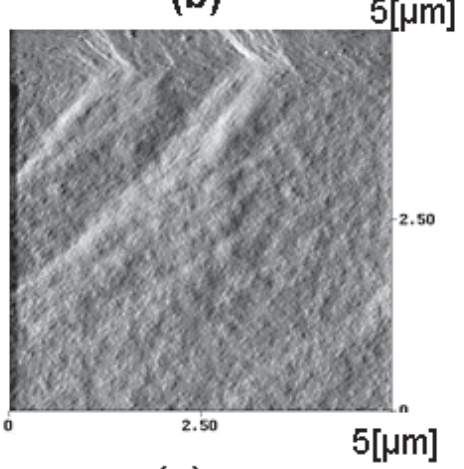

(e)
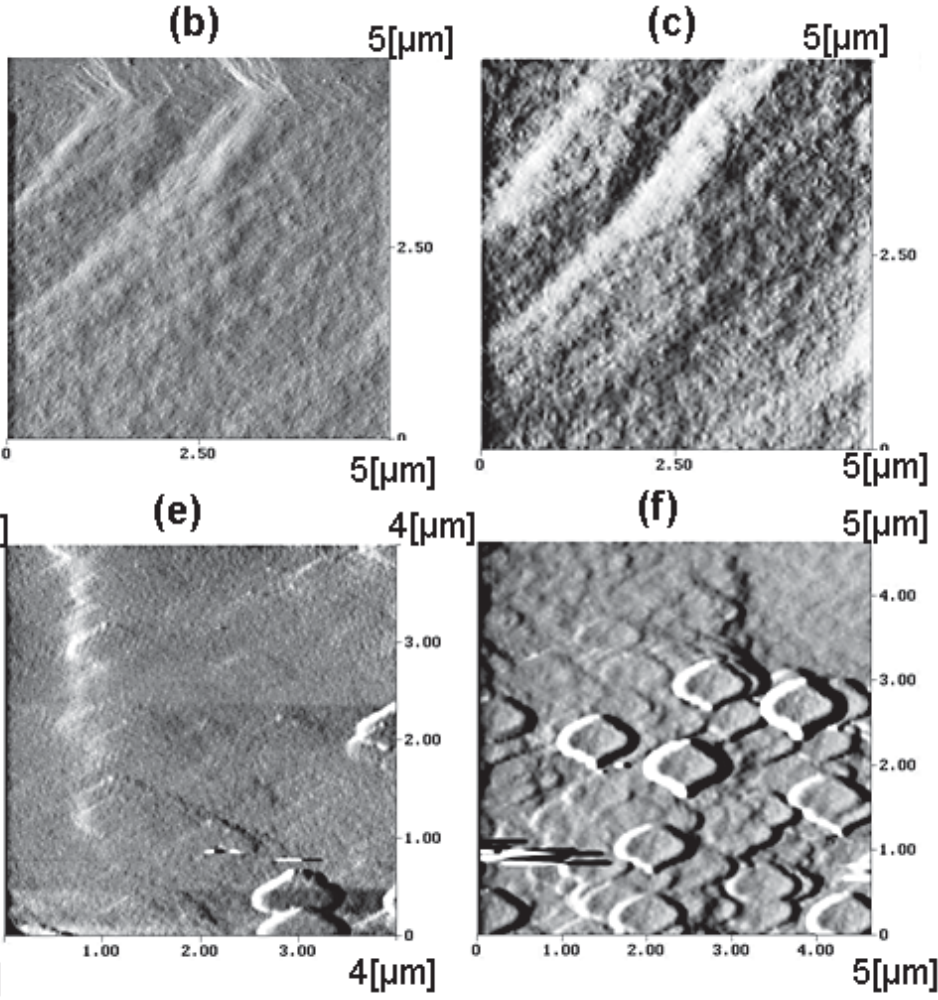

(f)

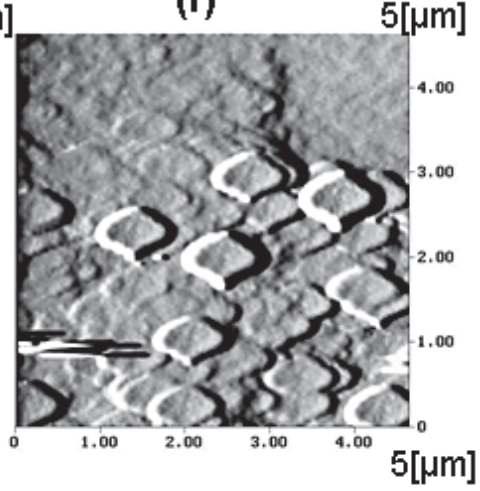

FIG. 3. (a) AFM image of a typical rhombohedral etch-pit on the calcite (104) surface after injection of deionized water. (b), (c) Precipitation of a fined-grained layer two and four minutes after injection of a $10 \mathrm{mmol} \mathrm{L}^{-1}$ uranyl nitrate solution with $\mathrm{pH}$ 2.5. (d) Formation of small crystallites of schoepite five minutes after injection. (e), (f) Formation of a layer of schoepite crystals (between five and ten minutes after injection; for details see text).

utes after injection of the solution (Fig. 5a). It is immediately apparent that the morphology of this crystal differs from those grown in the uranyl nitrate solution. The (001) face seems more rectangular in that the terminations of the prismatic crystal are not well defined (Fig. $4 \mathrm{e})$. Here, it is assumed that the crystals are elongate parallel to [010], in parallel with the observations on natural crystals of schoepite.

Figure $5 \mathrm{~b}$ shows a typical AFM image of schoepite crystals formed 10 minutes after injection of a $10 \mathrm{mmol}$ $\mathrm{L}^{-1}$ uranyl acetate solution. These elongate crystals have approximate lateral sizes between $250 \times 500$ and 300 $\times 600 \mathrm{~nm}$, and their thickness varies between 20 and $100 \mathrm{~nm}$. The elongate crystals have rounded terminations and show strong intergrowth. Irregular forms on one side of the crystals are presumably the product of strong tip-surface interactions.

Figure $5 \mathrm{c}$ shows elongate crystals of schoepite formed eight minutes after injection of a $5 \mathrm{mmol} \mathrm{L}^{-1}$ uranyl acetate solution. Figure $5 \mathrm{~d}$ shows a higher magnification of the crystals; their morphology is similar to that observed in the $10 \mathrm{mmol} \mathrm{L}^{-1}$ experiment.

\section{Morphology of Schoepite Crystals FROM BATCH EXPERIMENTS}

Figure 6a shows an AFM image of a schoepite crystal grown on the calcite (104) surface. The crystal grew in a uranyl acetate solution at room temperature for three days at a $\mathrm{pH}$ of $\sim 6.5$. Its lateral dimensions are $1300 \times$ $700 \mathrm{~nm}$, and its average thickness is approximately 100 unit-lengths in the $c$ direction $(\sim 150 \mathrm{~nm})$. The corresponding indices of the edges are [120], [110], [100], and [010].

Figure 6c also shows an AFM image of schoepite crystals formed on the calcite (104) surface. These crystals grew in a uranyl nitrate $-\mathrm{Na}_{2} \mathrm{CO}_{3}$ solution for three weeks in a $\mathrm{pH}$ range of $\sim 7.5-8.5$ (see above). The morphology of these schoepite crystals is nearly identical to that of the crystals in Figure 1c. Hence, the morphology of their (001) face is mainly characterized by [100] and [010] edges (Fig. 6c). In contrast to all other observations, these crystals grew on the surface with their (100) face parallel to the calcite (104) surface. 
(a)
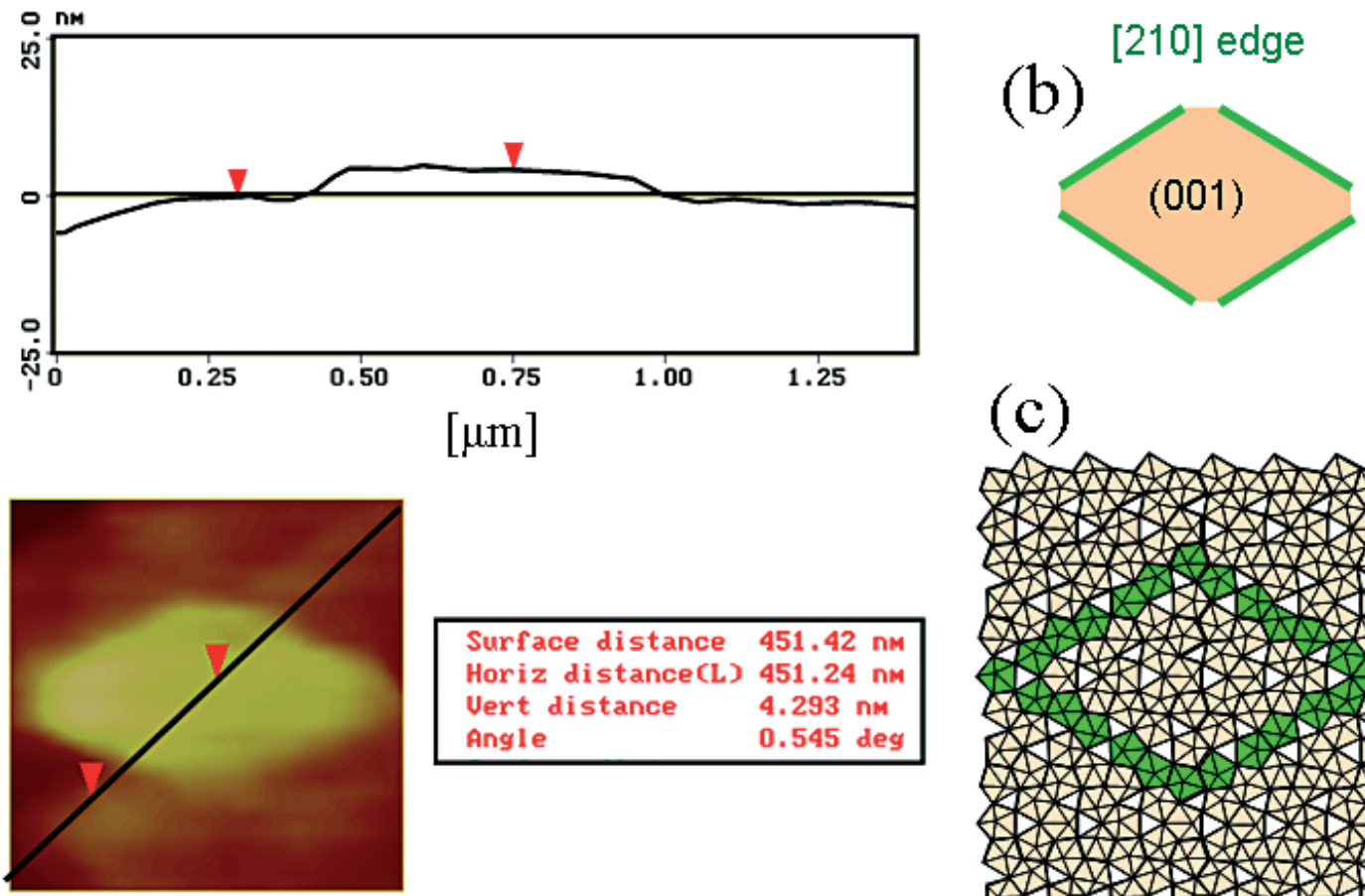

(c)

\begin{tabular}{|ll|}
\hline Surface distance & $451.42 \mathrm{~nm}$ \\
Horiz distance (L) & $451.24 \mathrm{~nm}$ \\
Vert distance & $\mathbf{4 . 2 9 3} \mathrm{nm}$ \\
Angle & $0.545 \mathrm{deg}$
\end{tabular}

FIG. 4. (a) A profile of an AFM height-image of one of the first schoepite crystals in Figure 3d. The average vertical and horizontal distances between the arrows along the profile are 4.293 and $451.24 \mathrm{~nm}$, respectively. (b) The morphology of the (001) face observed in the in situ experiments with the uranyl nitrate solution. The enclosed angles between the edges defining the (001) face are $c a \cdot 60^{\circ}$ and $120^{\circ}$. (c) The enclosed angles between the edges correspond to the enclosed angles between two chains of polyhedra parallel to [210] in the schoepite layer.

Schindler et al. (2004c) showed that during contact of a basic solution with calcite in an open vessel, the $\mathrm{pH}$ value drops from 10.0 to $7.5-8.0$, and the following uranyl minerals slowly form on the calcite (104) surface: $\left(\mathrm{UO}_{2}\right)^{2+}$-bearing calcite, uranyl tricarbonates (only at higher concentrations), wyartite II, becquerelite, and finally, schoepite. Figure 5b shows the common occurrence of schoepite (yellow), uranyl tricarbonates (green) and becquerelite (red) on the (104) surface of calcite. The schoepite crystals, which formed in a basic solution, might therefore have overgrown an earlier-formed phase. This underlying phase could not be identified via an AFM or SEM image, but its different structure-type (in comparison to calcite) might have changed the mechanism of epitactic growth of the overgrown crystals of schoepite.

\section{Discussion}

Strongly acidic uranyl solutions are usually undersaturated with respect to schoepite. If such solutions come in contact with calcite, the calcite starts to dissolve. This dissolution increases the $\mathrm{pH}$ and results in a supersaturation with respect to schoepite. This process can be divided into three steps:

(a) Dissolution of calcite and increasing value of $\mathrm{pH}$ :

$$
\mathrm{CaCO}_{3}+2 \mathrm{H}^{+} \leftrightarrow \mathrm{Ca}^{2+}+\mathrm{H}_{2} \mathrm{CO}_{3} *
$$

(b) Polymerization of the aqueous $\left(\mathrm{UO}_{2}\right)^{2+}$ species to more highly polymerized species:

$$
3\left(\mathrm{UO}_{2}\right)^{2+}+5\left(\mathrm{H}_{2} \mathrm{O}\right) \leftrightarrow\left[\left(\mathrm{UO}_{2}\right)_{3}(\mathrm{OH})_{5}\right]^{+}+5 \mathrm{H}^{+}
$$



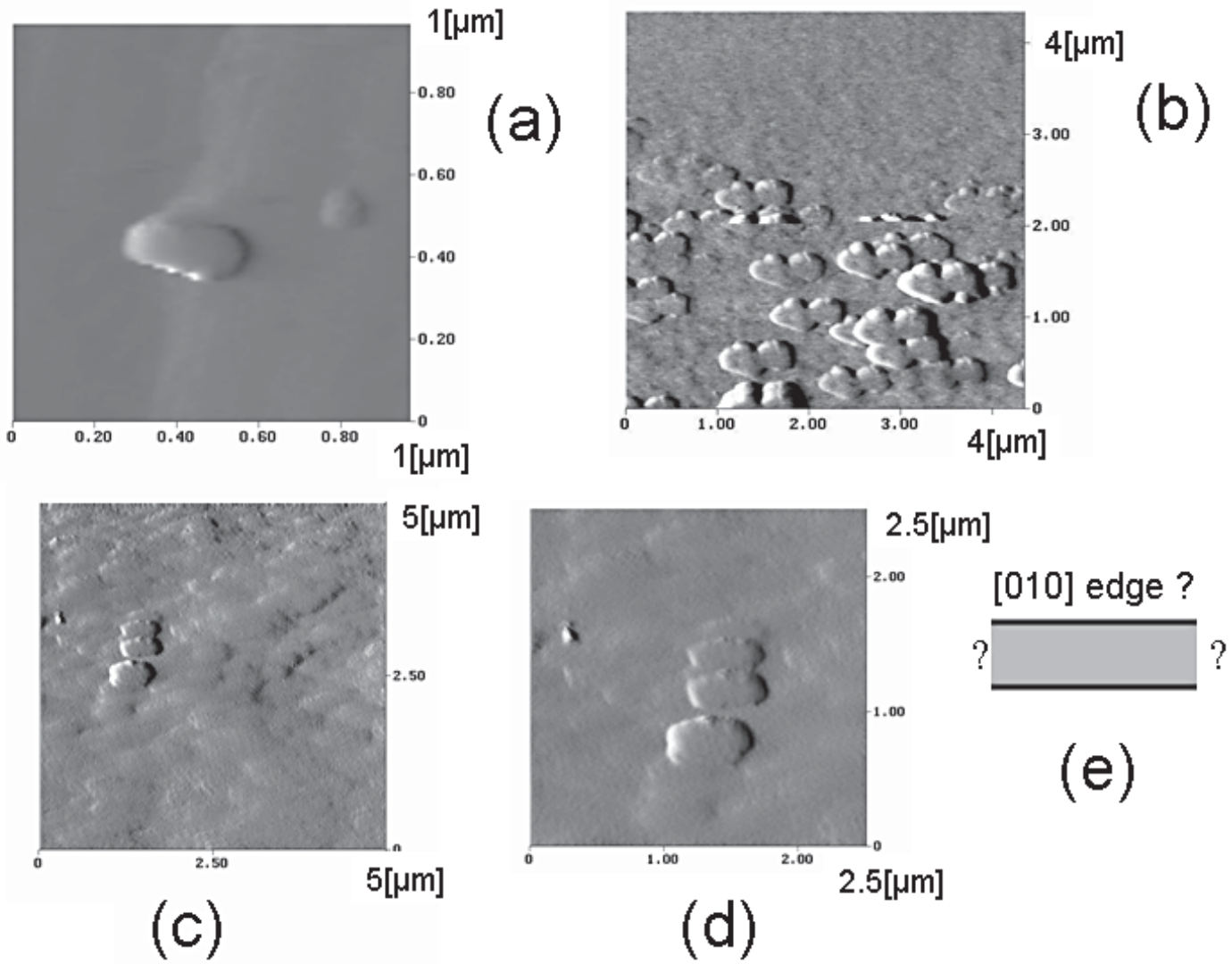

FIG. 5. (a) AFM image of a small growth-induced island two minutes after injection of a $10 \mathrm{mmol} \mathrm{L}^{-1}$ uranyl acetate solution. (b) AFM image of schoepite crystals formed 10 minutes after injection of a $10 \mathrm{mmol} \mathrm{L}^{-1}$ uranyl acetate solution. The prismatic crystals have rounded terminations and irregular forms on one side of the crystal. (c) AFM image of schoepite crystals grown four minutes after injection of an $5 \mathrm{mmol} \mathrm{L}^{-1}$ uranyl acetate solution. (d) Higher magnification of an AFM image of the same crystals as in (c). (e) The (001) face of the schoepite crystals, which is presumably elongate parallel to the [010] edge.

(c) Crystallization through polymerization of the aqueous species:

$$
\begin{aligned}
& 8\left[\left(\mathrm{UO}_{2}\right)_{3}(\mathrm{OH})_{5}\right]^{+}+14 \mathrm{H}_{2} \mathrm{O} \leftrightarrow \\
& 3\left[\left(\mathrm{UO}_{2}\right)_{8} \mathrm{O}_{2}(\mathrm{OH})_{12}\right]\left(\mathrm{H}_{2} \mathrm{O}\right)_{12}+8 \mathrm{H}^{+}
\end{aligned}
$$

Equation (1) shows that the dissolution of calcite increases the $\mathrm{pH}$ value as well as the activity of $\mathrm{Ca}^{2+}$ cations. Thus, the following question arises: why did we not observe the formation of any $\mathrm{Ca}^{2+}$ uranylhydroxy-hydrate minerals in the in situ experiments? Becquerelite, $\mathrm{Ca}\left[\left(\mathrm{UO}_{2}\right)_{3} \mathrm{O}_{2}(\mathrm{OH})_{3}\right]_{2}\left(\mathrm{H}_{2} \mathrm{O}\right)_{8}$, is the most important uranyl-hydroxy-hydrate mineral of $\mathrm{Ca}^{2+}$ and has a lower solubility than schoepite $(\log K=29.1$ : Casas et al. 1997). Therefore, in all in situ experiments, the solutions had higher saturation-indices with respect to becquerelite than to schoepite. For example, a $10 \mathrm{mmol}$ $\mathrm{L}^{-1}$ uranyl acetate solution of $\mathrm{pH} 6.5$, with an approximate concentration of $\left(10^{-4.5} / 2\right) \mathrm{mol} \mathrm{L}^{-1} \mathrm{Ca}^{2+}$, has a satu- ration index with respect to becquerelite $\beta_{\text {becquerelite }}$ of $10^{18.057}$, which is much higher than the corresponding saturation-index with respect to schoepite $\left(\beta_{\text {schoepite }}=\right.$ 13.77: Table 2).

A possible explanation would be that kinetic effects favor the more rapid formation of schoepite than of becquerelite. This would be in agreement with our crystal-growth experiments of becquerelite on calcite. These experiments indicate that becquerelite only forms in long-term batch experiments at $25^{\circ} \mathrm{C}$ (one week to three months) or, at $100^{\circ} \mathrm{C}$, in batch-experiments of one to two days (Schindler et al. 2004c).

\section{Change in morphology of schoepite crystals formed under different conditions}

The in situ and batch crystal-growth experiments described above have shown that the morphology of schoepite crystals changes with conditions in the solu- 
tions: crystals grown during the in situ experiments with uranyl nitrate solutions have a platy morphology, and their prominent (001) faces are defined by [210] edges. Crystals grown during the in situ experiments with a uranyl acetate solution seem more bulky and with a rectangular (001) face, which is presumably elongate parallel to [010]. Examinations of calcite surfaces that interacted with acidic or basic uranyl-bearing solutions for several days or weeks also reveal two different types of morphology: in the first case, schoepite forms platy asymmetrical crystals with prominent (001) faces, defined by [100], [010], [120], and [110] edges; in the second case, more bulky rectangular crystals of schoepite have (001) faces mainly defined by [100] and [010] edges.

\section{Morphology-controlling parameters}

Sunagawa (1987) listed the following principal factors controlling the habit of crystals: (a) type of phase, (b) type of solvent, (c) growth temperature, (d) degree of supersaturation, and (e) impurities.

We can exclude as controlling factors in these experiments the type of phase, type of impurities and the growth temperature, because those factors are nearly identical in the in situ and batch crystal-growth experiments. What factors do change are the degree of supersaturation and the type of solvent. In uranyl nitrate and uranyl acetate solutions of the in situ experiments, the ranges in $\mathrm{pH}$ and the saturation indices with respect to schoepite were different. The larger crystals observed in the long-term batch experiments presumably grew closer to equilibrium than the crystals in the in situ experiments, i.e., the corresponding solutions were less strongly supersaturated with respect to schoepite.

\section{Supersaturation and $F$ and $S$ faces}

on schoepite crystals

Hartman \& Perdok (1955a, b, c) showed that the morphology of a crystal can be explained through the occurrence of uninterrupted chains of strong bonds in the internal structure, which they called Peridiodic Bond Chains (PBC). In the structure of schoepite, the PBC run parallel to the chains of polyhedra in the uranylhydroxy-hydrate sheet (Fig. 2a). According to the PBC theory, the (001) face of schoepite is therefore an F face because the corresponding sheet (i.e., structural unit) contains more than two periodic bond-chains. The edges defining the (001) face can be represented by chains of polyhedra in the sheet-structural unit (Fig. 2a, Schindler et al. 2004a). These edges are therefore part of S faces, which contain only one type of periodic bond-chain. Normally, an F face grows by growth of two-dimensional steps and develops into a larger face, whereas an $\mathrm{S}$ face grows by a one-dimensional layer-by-layer growth and develops into a smaller face (Figs. 7b, c). Growth processes of schoepite crystals can therefore be defined by different growth-rates on $\mathrm{F}$ and $\mathrm{S}$ faces. The growth rate in the two-dimensional layer can be characterized by the lateral area in $\mu \mathrm{m}^{2}$, and the growth rate of the $\mathrm{S}$ faces, by the thickness of the crystals in the $c$ direction. Figure 7 a shows the correlation between the growth rates of $\mathrm{F}$ and $\mathrm{S}$ faces on schoepite crystals observed in the in situ experiments with $10 \mathrm{mmol} \mathrm{L}^{-1}$ uranyl acetate and uranyl nitrate solutions over a time range of 4 to 15 minutes after injection. It is apparent that, under higher supersaturation in the uranyl acetate solution, the growth rate of the $\mathrm{S}$ face is higher than under lower supersaturation in the uranyl nitrate solution. This is in agreement with the generally observed tendency that under higher supersaturation, $\mathrm{K}$ or $\mathrm{S}$ faces predominantly develop, whereas under lower supersaturation, $\mathrm{F}$ faces predominate (Bienfait et al. 1965, Hartman 1965a, b).

\section{Comparison between the predictions}

of Schindler et al. (2004b) and the observed edges in the crystal-growth observations on calcite

The predictions of Schindler et al. (2004b) agree well with the observations in the batch experiments. The crystals of the batch experiment under acidic conditions presumably grew in a low-supersaturation solution close to $\mathrm{pH} 6.5$ (Fig. 6a). Hence, the crystals grew in a solution close to the range of PZC values of the edges (see above). These conditions are preserved in the morphology of its (001) face, which contains [100], [010], [120], and [110] edges. The crystals from the batch experiments at basic conditions presumably grew at similar supersaturations, but at higher values of $\mathrm{pH}$ (in the range 7.5-8.5; Fig. 6c). Thus, the corresponding solution had larger differences between $\mathrm{pH}$ and PZC (ca. 0.5-1.5), which are preserved by the occurrence of the [100] and [010] edge.

Schindler et al. (2004b) predicted that the (001) face of schoepite crystals should be defined by [100] and [010] edges if the crystals grow under high supersaturations. A high supersaturation occurs in both in situ experiments, whereby the saturation indices in the uranyl acetate experiment are higher than in the uranyl nitrate experiment (see above). The crystals grown in the uranyl acetate experiment display the elongate morphology of schoepite crystals where the (001) face is defined by [100] and [010] edges. However, their morphology can be better characterized as a rough surface and rounded edges and faces, which are typical features of growth under highly supersaturated conditions. As a result, the occurrence of specific edges on the (001) face could not be unequivocally determined.

In the in situ uranyl nitrate experiment, the (001) face of the schoepite crystals is defined by the [210] edges, which is not in agreement with the predictions of Schindler et al. (2004b). A possible explanation could be the presence of inner-sphere complexes between aqueous species and anion terminations along the [210] 
edge. Schindler et al. (2004b) did not consider these complexes, because their occurrence depends on the activity and crystal-chemical properties of aqueous species in solution.

\section{Application to the crystal morphologies of schoepite in mineral samples}

The crystal growth of schoepite in the batch experiments showed that the edges [100] and [010] mainly define the (001) face of schoepite crystals, which grow in solutions with large differences between $\mathrm{pH}$ and PZC. Edges such as [120] and [110] occur on (001) faces, encountered where the crystals grow in solutions having small differences between $\mathrm{pH}$ and PZC. Further, the in situ experiments showed that the growth rate of S faces increases with increasing supersaturation.

We can now apply this knowledge to the crystal morphologies of mineral samples shown in Figure 1. The (001) face of all these crystals is elongate parallel [010], which is presumably a result of the predicted higher stability of the [010] edge with respect to the [100] edge. Further, the crystals in Figure 1a might have grown at conditions close to the point of zero charge and at low supersaturations. The prismatic crystals of Figure $1 \mathrm{~b}$ show well-developed $\mathrm{S}$ faces, which may indicate a high supersaturation of the mother solution. The crystals of Figure 1c are nearly identical to the crystals grown under basic conditions in our batch experiments. Hence, they might have grown in a solution at low su-

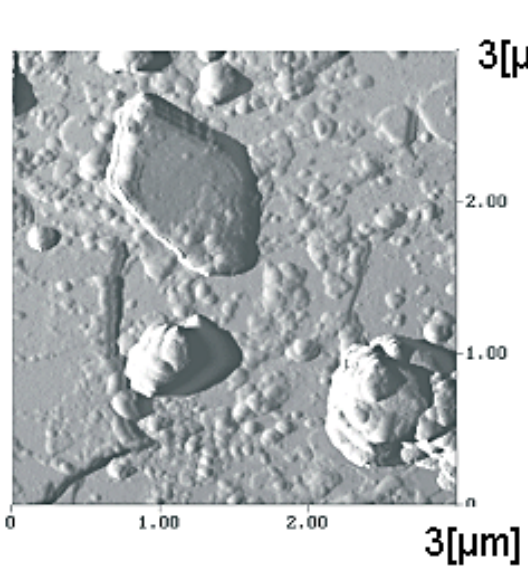

(b)

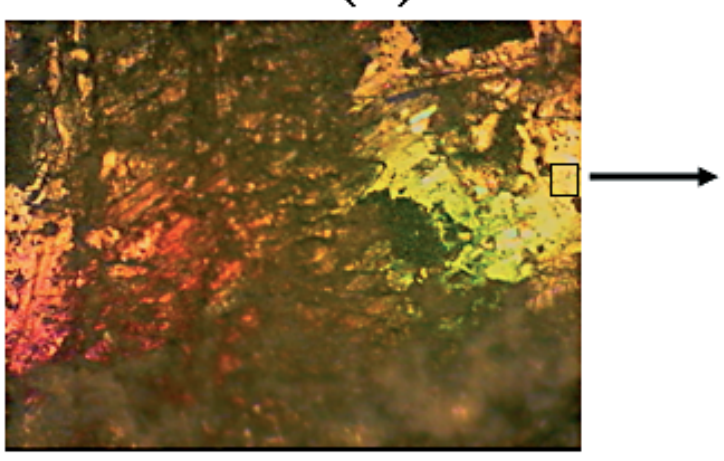

$500 \mu \mathrm{m}$

(a)
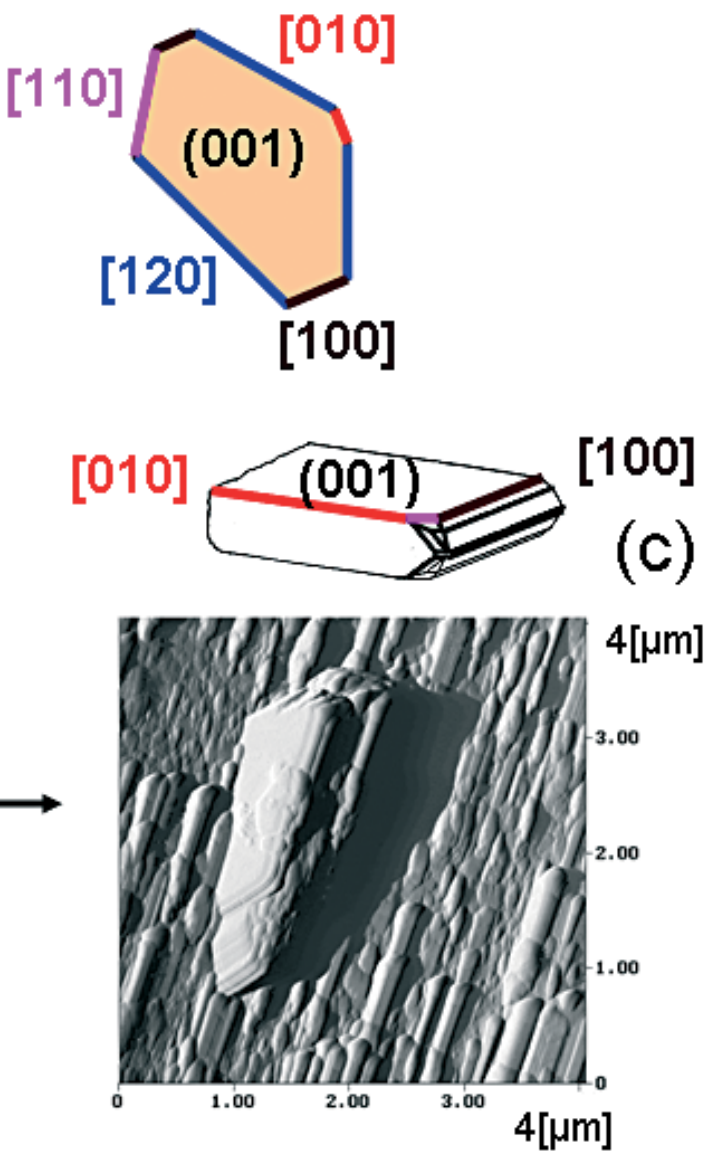

FIG. 6. (a) AFM image of a crystal of schoepite grown in a weakly acidic solution on a calcite (104) surface; the (001) face is defined by [120], [110], [100] and, [010] edges. (b) Common occurrence of schoepite (yellow), uranyl tricarbonates (green) and becquerelite (red) on calcite after three weeks of interaction with an basic uranyl-bearing solution; area marked with a black rectangle indicates scanning area of the AFM image in (c). (c) Corresponding crystals of schoepite on calcite; their morphology is similar to that of crystals from Kasolo, Democratic Republic of Congo (Palache et al. 1944). 
persaturation and large differences between $\mathrm{pH}$ and PZC.

\section{Conclusions}

Atomic-force-microscope examinations of the interaction between uranyl-bearing solutions and the (104) surface of calcite have, for the first time, revealed in situ images of the crystal growth of schoepite. The use of uranyl solutions with different values of $\mathrm{pH}$ and saturation indices results in different morphologies of the schoepite crystals. Their thickness was related to the different growth-rate of $\mathrm{S}$ faces under different supersaturations. The different pattern of occurrence of edges could be partly explained with a new method developed by Schindler et al. (2004a, b).

\section{ACKNOWLEDGEMENTS}

We thank Petre Mandaliev for his enormous help and Carlos Pina and Andreas Mutter for discussions. This work was supported by an Emmy Noether Fellowship from the Deutsche Forschungsgemeinschaft to MS. We also thank Associate Editor Allan Pring, two anonymous reviewers, and Robert F. Martin.

\section{REFERENCES}

Bienfait, M., Boistelle, R. \& Kern, R. (1965): Formes de croissance des halogénures alcalins dans un solvant polaire; les morphodromes de $\mathrm{NaCl}$ en solution et l'adsorption d'ions étrangers. In Adsorption et Croissance Cristalline, C.V.R.S., 515-535, 577-594.

BucK, E.C., Finch, R.J., FinN, P.A. \& BAtes, J.K. (1998): Np in dehydrated schoepite. In Scientific Basis for Nuclear Waste Management XXI (I.A. McKinley \& C. McCombie, eds.). Mater. Res. Soc., Proc. 506, 87-94.

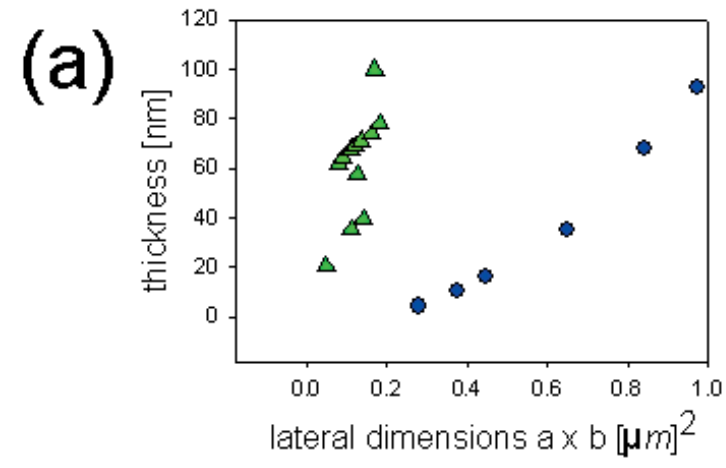

$$
\begin{aligned}
& \text { Uranyl-acetate solution, } \\
& \beta_{\text {initial }}=2, \beta_{\text {final }}=13.8 \\
& \text { Uranyl-nitrate solution, } \\
& \beta_{\text {initial }}=0, \beta_{\text {final }}=6.3
\end{aligned}
$$
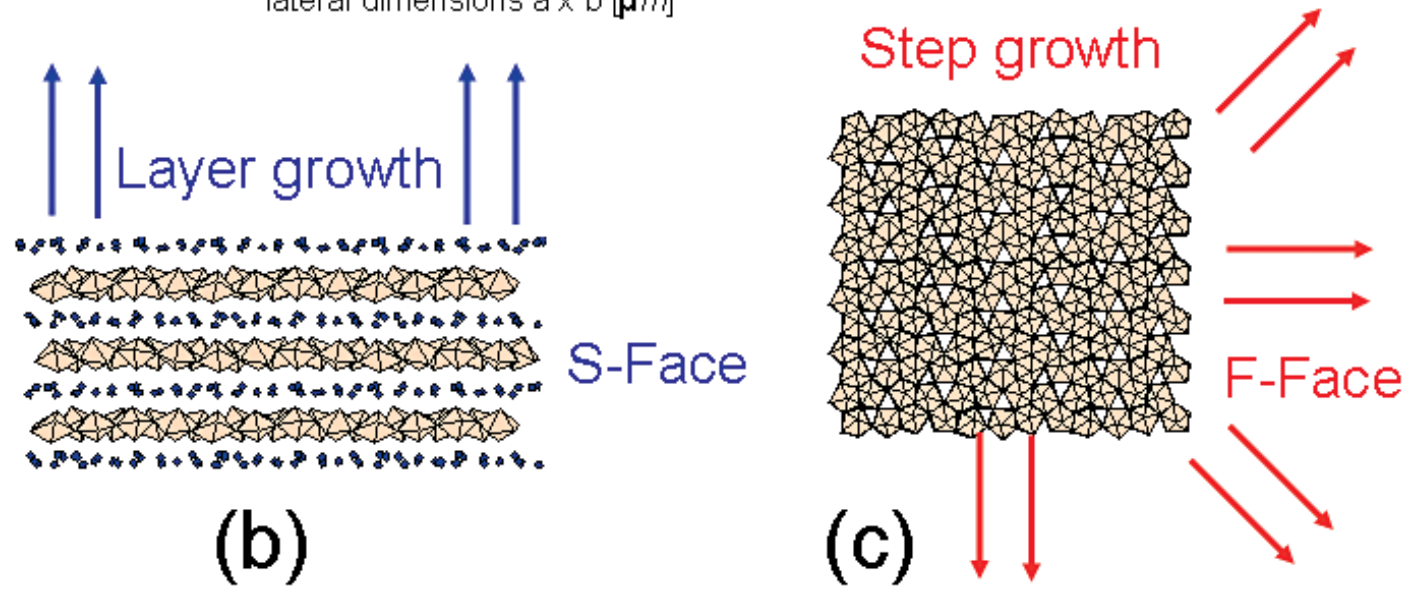

FIG. 7. (a) The lateral area of schoepite crystals $\left(\right.$ in $\mu \mathrm{m}^{2}$ ) versus their thickness (in $\mathrm{nm}$ ) grown in a time range of 4 to 15 minutes after injection of the solution; green triangles and blue circles represent crystals grown in the in situ experiments with uranyl actate and uranyl nitrate solutions, respectively. (b) The growth of a S face by a one-dimensional layer growth is indicated with blue arrows. (c) The growth of an F face by two-dimensional step growth is indicated with red arrows. 
Wronkiewicz, D.J., Finn, P.A. \& BAtes, J.K. (1997): A new uranyl oxide hydrate phase derived from spent fuel alteration. J. Nucl. Mater. 249, 70-76.

Burns, P.C. \& Li, YAPING (2002): The structures of becquerelite and Sr-exchanged becquerelite. Am. Mineral. 87, 550-557.

Caroll, S.A., Bruno, J., Petit, J.-C. \& Dran, J.C. (1992): Interaction of $\mathrm{U}(\mathrm{VI}), \mathrm{Nd}$, and $\mathrm{Th}(\mathrm{IV})$ at the calcite-solution interface. Radiochim. Acta 58/59, 245-252.

Casas, I., Bruno, J., Cera, E., Finch, R.J. \& Ewing, R.J. (1997): Characterization and dissolution behaviour of a becquerelite from Shinkolobwe, Zaire. Geochim. Cosmochim. Acta 61, 3879-3884.

Christ, C.L. \& Clark, J.R. (1960): Crystal chemical studies of some uranyl oxide hydrates. Am. Mineral. 45, 10261061.

Deliens, M. (1977): Associations de minéraux secondaires d'uranium à Shinkolobwe (région du Shaba, Zaïre). Bull. Soc. fr. Minéral. Cristallogr. 100, 32-38.

Finch, R.J., CoOper, M.A., Hawthorne, F.C. \& Ewing, R.C. (1996): The crystal structure of schoepite, $\left[\left(\mathrm{UO}_{2}\right)_{8} \mathrm{O}_{2}\right.$ $\left.(\mathrm{OH})_{12}\right]\left(\mathrm{H}_{2} \mathrm{O}\right)_{12}$. Can. Mineral. 34, 1071-1088.

\& EwING, R.C. (1992): The corrosion of uraninite under oxidizing conditions. J. Nucl. Mater. 190, 133-156.

, Hawthorne, F.C. \& Ewing, R.C. (1998): Structural relations among schoepite, metaschoepite and "dehydrated schoepite". Can. Mineral. 36, 831-845.

Miller, M.L. \& Ewing, R.C. (1992): Weathering of natural uranyl oxide hydrates: schoepite polytypes and dehydration effects. Radiochim. Acta 58/59, 433-443.

ForSYTH, R.S. \& WeRME, L.O. (1992): Spent fuel corrosion and dissolution. J. Nucl. Mater. 190, 3-19.

Frondel, C. (1958): Systematic mineralogy of uranium and thorium. U.S. Geol. Surv., Bull. 1064.

Geipel, G., Reich, T., Brendler, V., Bernhard, G. \& NitsCHE, H. (1997): Laser and X ray spectroscopic studies of uranium-calcite interface phenomena. J. Nucl. Mater. 248, 408-411.

Grenthe, I., Fuger, J., Konings, R.J.M., Lemire, R.J., Muller, A.B., Nguyen Trung, C. \& Wanner, H. (1992): Chemical Thermodynamics. North Holland, Amsterdam, The Netherlands.

Gustafson, J.P. (2003): Visual MINTEQ, Version 2.22. KTH, Department of Land and Water Resources Engineering, Stockholm, Sweden.

Hartman, P. (1965a): Le coté cristallographique de l'adsorption vu par le changement de facies. In Adsorption et Croissance Cristalline, C.V.R.S., 477-513. (1965b): Habit variation of brookite in relation to the paragenesis. In Adsorption et Croissance Cristalline, C.V.R.S., 597-614

\& PERDOK, W.G. (1955a): On the relations between structure and morphology of crystals I. Acta Crystallogr. 8 49-52.

$\&$ (1955b): On the relations between structure and morphology of crystals II. Acta Crystallogr. 8, 521-524.

\& (1955c): On the relations between structure and morphology of crystals III. Acta Crystallogr. 8, 525-529.

HILL, F.C. (1999): Identification of selected uranium-bearing minerals and inorganic phases by X-ray powder diffraction. Rev. Mineral. 38, 653-679.

KitANO, Y. \& OOMORI, T. (1971): The coprecipitation of uranium with calcium carbonate. J. Ocean. Soc. Japan 27, 34-42.

Mason, C.F.V., Turney, W.R.J.R., Thompson, B.M., Lu, N., Longmire, P.A. \& Chrisholm-Brause, C.J. (1997): Carbonate leaching of uranium from contaminated soils. Environ. Sci. Tech. 31, 2707-2711.

MeEce, D.E. \& Benninger, L.K. (1993): The coprecipitation of $\mathrm{Pu}$ and other radionuclides with $\mathrm{CaCO}_{3}$. Geochim. Cosmochim. Acta 57, 1447-1458.

Morse, J.W., Shanbhag, P.M., Saito, A. \& Choppin, G.R (1984): Interaction of uranyl ions in carbonate media. Chem. Geol. 42, 85-99.

Palache, C., Berman, H. \& Frondel, C. (1944): The System of Mineralogy (7th ed.). John Wiley \& Sons, New York, N.Y.

Perloff, L. (1998) : The Photo-Atlas of Minerals (A.R. Kampf \& G. Gerhold, eds.). The Gem and Mineral Council, Los Angeles County Museum of Natural History, Los Angeles, California.

ReEder, R.J., Nugent, M., LAmble, G.M., Tait, C.D. \& MorRIS, D.E. (2000): Uranyl-incorporation into calcite and aragonite: XAFS and luminescence studies. Environ. Sci. Tech. 34, 638-644.

, TAIT, C.D., Morris, D.E., Heald, S.M., Beck, K.M., Hess, W.P. \& Lanzirotti, A. (2001): Coprecipitation of uranium(VI) with calcite: XAFS, micro$\mathrm{XAS}$, and luminescence characterization. Geochim. Cosmochim. Acta 65, 3491-3503.

Schindler, M., Hawthorne, F.C., Putnis, C. \& Putnis, A (2004c): Growth of uranyl-hydroxy-hydrate and uranyl carbonate minerals on the (104) surface of calcite. Can. Mineral. 42, 1683-1697.

Mutter, A., Hawthorne, F.C. \& Putnis, A. (2004a): Prediction of crystal morphology of complex ura- 
nyl-sheet minerals. I. Theory. Can. Mineral. 42, 16291649.

\&__ (2004b): Prediction of crystal morphology of complex uranyl-sheet minerals. II. Observation. Can. Mineral. 42, 1651-1666.

Stumm, W. (1992): Chemistry of the Solid-Water Interface. John Wiley \& Sons, New York, N.Y.

Sunagawa, I. (1987): Morphology of minerals. In Morphology of Crystals (I. Sunagawa, ed.). Terrapub, Tokyo, Japan (509-587).

Sunder, S., Shoesmith, D.W., Christensen, H. \& Miller, N.H. (1992): Oxidation of $\mathrm{UO}_{2}$ fuel by the products of gamma radiolysis of water. $\mathrm{J}$. Nucl. Mater. 190, 78-86.

TAYLOR, J.C. \& HURST, H.J. (1971): The hydrogen atom locations in the $\alpha$ and $\beta$ forms of uranyl hydroxide. Acta Crystallogr. B27, 2018-2022.

Torrero, M.E., Casas, I., De Pablo, J., Sandino, M.C.A. \& Grambow, B. (1994): A comparison between unirradiated $\mathrm{UO}_{2}(\mathrm{~s})$ and schoepite solubilities in $1 \mathrm{~m} \mathrm{NaCl}$ medium. Radiochim. Acta 66/67, 29-35.

United Nations Environment Program (2001): Depleted uranium in Kosovo (2001). Post-conflict environmental assessment.
WADSEN, T. (1977): The oxidation of polycrystalline uranium dioxide in air at room temperature. J. Nucl. Mater. 64, 315.

WALKER, T.L. (1923): Schoepite, a new uranium mineral from Kasolo, Belgian Congo. Am. Mineral. 8, 67-69.

WANG, R. \& Katayama, J.B. (1982): Dissolution mechanism for $\mathrm{UO}_{2}$, and spent fuel. Nucl. Chem. Waste Manag. 3, 8390.

Wronkiewicz, D.J., Bates, J.K., Gerding, T.J., Veleckis, E. \& TANI, B.S. (1992): Uranium release and secondary phase formation during unsaturated testing of $\mathrm{UO}_{2}$ at $90^{\circ} \mathrm{C} . J$. Nucl. Mater. 190, 107-127.

Wolf, S.F. \& BuCK, E.C. (1996): Ten year results from unsaturated drip tests with $\mathrm{UO}_{2}$ at $90^{\circ} \mathrm{C}$ : implications for the corrosion of spent nuclear fuel. J. Nucl. Mater. 238, 78-95.

Yu, A., Teterin, K.E., Ivanov, A.S., Baev, S., Nefedov, V.I., GeIPEL, G., Reich, T. \& Nitsche, H. (1988): X-ray photoelectron study of the interaction of $\mathrm{UO}_{2}\left(\mathrm{ClO}_{4}\right)_{2}$ with calcite and diabase minerals in water solutions. Surf. Invest. 13, 613-622.

Received March 19, 2003, revised manuscript accepted July 20, 2004. 